\title{
Physicochemical, Atwater Factor and Acceptability Changes of Moi-Moi from Cowpea (Vigna unguiculate (L) Walp) as a Function of White Maize Substitution
}

\author{
Okwunodulu, N. Innocent ${ }^{1, a *}$, Osuagwu, C. Chisom ${ }^{1, b}$, \\ Onwuzuruike, U. Anselm ${ }^{1, \mathrm{c}}$, Uzochukwu, U. Comfort ${ }^{1}$ \\ ${ }^{1}$ Department of Food Science and Technology, College of Applied Food Sciences and Tourism, \\ Michael Okpara University of Agriculture, Umudike, Abia State, Nigeria. \\ *anncntokwu@yahoo.com, bosuagwupretty@gmail.com, cuzohanselm@gmail.com
}

Keywords: Physicochemical, Atwater, acceptability, white maize, moi-moi, cowpea.

\begin{abstract}
Cereal grains complement legumes when consumed together in a beneficial ratio to gives good quality protein. Maize protein is deficient in lysine but rich in sulphur containing amino acids lacking in cowpea thereby complementing that to enhance the nutritive value of the moi-moi. Cowpea white maize moi-moi samples were produced from cowpea and white maize blending ratio (\%) of 95: 5, 90: 10 and 80: 20 while moi-moi produced from 100\% cowpea (CP100:WM0) served as control sample. Proximate, mineral, vitamin and physicochemical composition were evaluated with standard analytical methods. Energy values were by calculation using Atwater general factor system (AGFS) and sensory scores were by subjective means with 25 semi-trained panelists. With increasing white maize substitution of cowpea, crude fibre (1.40 to1.47\%), ash (1.41 to1.70\%), carbohydrate (17.31 to $31.51 \%$ ), energy ( 241.50 to $279.08 \mathrm{Kcal})$, vitamin A (1.33 to $1.63 \mu \mathrm{g} / 100 \mathrm{~g}$ ), calcium (17.07 to18.94 mg/100g), magnesium (12.38 to $13.17 \mathrm{mg} / 100 \mathrm{~g}$ ), phosphorous (7.20 to $7.53 \mathrm{mg} / 100 \mathrm{~g}$ ) and colour (0.13 to 0.29$)$ were increased. But moisture (48.53 to $37.82 \%$ ), protein (20.52 to18.82\%), fat (10.02 to 8.64\%), vitamin C (0.04 to $0.03 \mathrm{mg} / 100 \mathrm{~g}), \mathrm{pH}(6.05$ to 5.83$)$, and general acceptability (7.10 to 5.70) were decreased. The control sample, 100\% cowpea moi-moi had the best organoleptic properties. Increasing substitution of cowpea with white maize resulted in acceptable moi-moi samples at lower levels with significant $(\mathrm{p}<0.05)$ nutritional changes.
\end{abstract}

\section{Introduction}

Moi-moi is a steamed seasoned (vegetable oil, Cray-fish, salt among others) soft gel prepared from wet-dehulled and wet-milled cowpea (Vigna unguiculata Walp) paste packaged in leaves or aluminum foil. Upon cooling, it solidifies to assume the shapes (pyramid or cylindrical) of packaging materials used. It is an economic protein-rich snack consumed with pap (ogi) and rice as breakfast meals in most Nigeria homes [1,2].

Cowpea is the major legume [5] for preparing moi-moi, akara, danwake among others which traditional preparation method is laborious and time consuming, hence the use of cowpea flours [6, 7] to avoid soaking, dehulling, and wet milling. Besides, cowpea can be cooked with cereal grain like rice or with tubers like yam, cocoyam, and potatoes and consumed as major protein sources [3, 4]. Cowpea anti-nutrients [9, 10] are removed or reduced by dehulling, soaking, cooking, germination, fermentation among others. Though some of these processes may individually or collectively reduce some nutrients $[8,11]$, but steeping and germination increase same and their bioavailability, and decrease anti-nutrients [6]. However, dehulling of cowpea seeds removes the much needed dietary fibre which health benefits include among others healthy digestive system, reduced risk of chronic diseases such as diabetes, obesity, lowering bad cholesterol and postprandial glucose up surge [11].

Maize is considered as a staple food [12] that is ranked second most important cereal crop behind sorghum in Nigeria based on the number of people it feeds [13]. Due to its higher yielding potential compared to other cereals, it is globally termed as queen of cereals [14]. Maize contains various nutrients and health benefits; hence its wide use for human foods. Maize is deficient in 
proteins and essential amino acids such as lysine and tryptophane and therefore not a good protein source, but rich in calories.

Cereal grains and legumes mutually complement each other when consumed together in a beneficial ratio (7 legume: 18 cereal) to provide a better amino-acid profile [15]. Lysine deficient maize protein, rich in sulphur containing amino acids, supplements sulphur deficient cowpea, rich in lysine. Cooking of legume-cereal based foods (breadfruit and maize meal) and consumption of $o g i$ with akara or moi-moi, bread with akara or boiled cowpea among others in Nigeria is an age long menu which origin is uncertain. The aim of this study was to improve the nutrient and acceptability status of moi-moi for both young and adults by supplementing it with maize.

\section{Materials and Methods}

Cowpea, white maize, aluminum foil and the ingredients used were procured from Urbani main market in Umuahia North Local Government Area of Abia State, Nigeria.

\section{Preparation of cowpea-white maize moi-moi}

Cowpea-white maize moi-moi samples was prepared (Figure 1) by separately sorting, cleaning and respectively steeping in tap water for $20 \mathrm{~min}$ and $2 \mathrm{~h}$. Each was drained thereafter and cowpea was hand dehulled and the hulls were removed by water floatation while white maize was washed with clean water to obtain steeped cowpea cotyledons and white maize respectively which was blended (Table 1). Each blend which represents a sample was mixed separately in a bowl with warm water and recipes (Table 2). The mixture was then milled, properly mixed, wrapped in aluminum foil, cooked for $30 \mathrm{~min}$ and cooled to obtain moi-moi samples.

Table 1: Cowpea and white maize blend ratios for moi-moi production.

\begin{tabular}{ccc} 
Sample codes & Cowpea $(\%)$ & White maize $(\%)$ \\
\hline $\begin{array}{c}\text { CP100:WM0 } \\
\text { (control) }\end{array}$ & 100 & 0 \\
CP95: WM5 & 95 & 5 \\
CP90: WM10 & 90 & 10 \\
CP80:WM20 & 80 & 20 \\
\hline
\end{tabular}


Table 2: Recipe for moi-moi production

Ingredients Quantity

Cowpea $\quad 365 \mathrm{~g}$

White Maize $\quad 35 \mathrm{~g}$

Warm water $\quad 1104 \mathrm{ml}$

Vegetable oil $\quad 200 \mathrm{ml}$

Ground red pepper $\quad 50 \mathrm{~g}$

Onion $\quad 40 \mathrm{~g}$

Salt $\quad 11 \mathrm{~g}$

Crayfish $\quad 10 \mathrm{~g}$

Mixed spice $1 \mathrm{~g}$

Maggi cube $\quad 1 \mathrm{~g}$ 


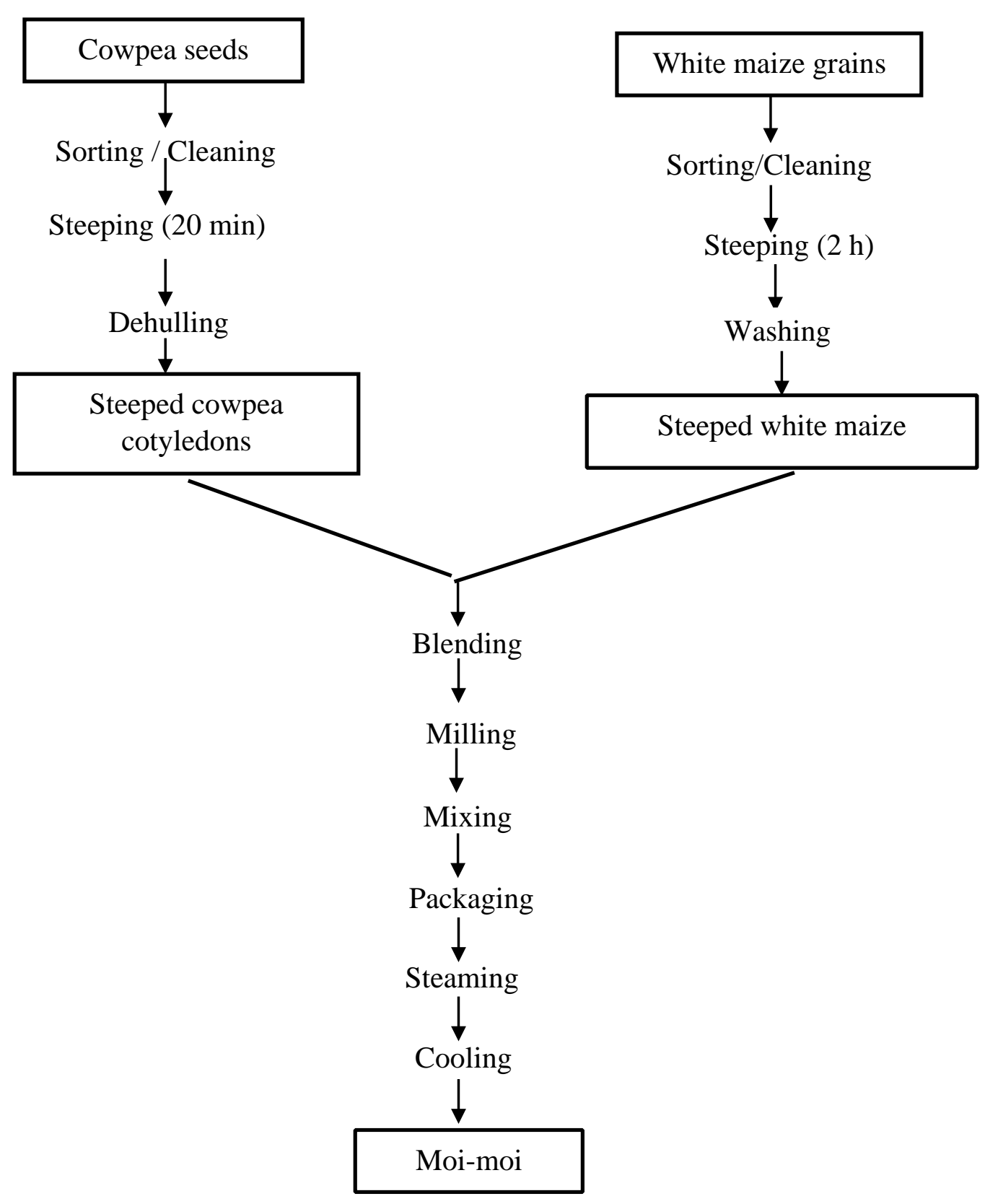

Figure 1: Flow chart for preparation of cowpea-white maize moi-moi sample

\section{Analyses}

All the moi-moi samples were subjected to proximate, nutrient, physicochemical and acceptability analyses separately in triplicates as stated below. The mean of the triplicate values were used for statistical analyses.

\section{Moisture content determination}

Moisture content was determined according to AOAC [16].Ten grams (10 g) of the sample were measured into previously weighed moisture cans $\left(\mathrm{W}_{1}\right)$. The sample in the can $\left(\mathrm{W}_{2}\right)$ was dried in the oven at $105^{\circ} \mathrm{C}$ for $3 \mathrm{~h}$, cooled in desiccators and reweighed. This process was repeated several times but at 30 min interval until a constant weight was obtained, thereafter was cooled in desiccators, reweighed. The final dry weight was recorded $\left(w_{3}\right)$ and used to calculate the percentage moisture content of the sample as shown below: 
$\%$ Moisture content $=\frac{\mathrm{W}_{2}-\mathrm{W}_{3}}{\mathrm{~W}_{2}-\mathrm{W}_{1}} \times \frac{100}{1}$

Where $\mathrm{W}_{1}=$ initial weight of empty can

$\mathrm{W}_{2}=$ weight of can + sample before drying

$\mathrm{W}_{3}=$ weight of can + sample after drying

\section{Crude protein determination}

The method described by AOAC [16] was used. Total nitrogen $\left(\mathrm{N}_{2}\right)$ was determined and multiplied with factor 6.25 to obtain the protein content. One gram $(1.0 \mathrm{~g})$ of the sample was mixed with $10 \mathrm{ml}$ of concentrated $\mathrm{H}_{2} \mathrm{SO}_{4}$ in a digestion flask. A tablet of selenium catalyst was added and heated in a fume cupboard until a clear solution (the digest) was obtained which was diluted to $100 \mathrm{ml}$ in a volumetric flask. $10 \mathrm{ml}$ of the digest was mixed with equal volume of $45 \% \mathrm{NaOH}$ solution in a kjeldahl distillation apparatus. The mixture was diluted into $10 \mathrm{ml}$ of $4 \%$ buric acid containing 3 drops of mixed indicator (bromoscresssol green/methyl red). A total of $50 \mathrm{ml}$ of distillates was collected and titrated against $0.02 \mathrm{~N}$ EDTA from green to deep red end point. The $\mathrm{N}_{2}$ obtained was used to calculate protein as below: \% Protein $=\% \mathrm{~N}_{2} \times 6.25$

$\% \mathrm{~N}_{2}=\left(\frac{100}{\mathrm{~W}} \times \frac{\mathrm{Nx} 14}{1000} \times \frac{\mathrm{Vt})}{\mathrm{Va}} \mathrm{TBK}\right.$

Where: $\mathrm{W}=$ weight of sample

$\mathrm{N}=$ normality of titan $\left(0.02 \mathrm{H}_{2} \mathrm{SO}_{4}\right)$

$\mathrm{Vt}=$ total digest volume $(100 \mathrm{~m} / \mathrm{s})$

$\mathrm{Va}=$ volume of digest analyzed $(10 \mathrm{ml})$

$\mathrm{T}=$ titre value of sample

$\mathrm{B}=$ titre value of blank

\section{Determination of ash}

The method described by AOAC [16] was used. Three grams (3 g) of the sample were added to a weighed dried porcelain crucible and ignited in the muffle furnace at $550^{\circ} \mathrm{C}$. The sample was allowed for $3 \mathrm{~h}$ to ash to a grayish white ash, brought out from the furnace using a forceps and left in a desiccators to cool. The ash was weighed and percent ash was calculated as shown below:

$\%$ Ash $=\frac{\mathrm{w}_{3}-\mathrm{w}_{1}}{\mathrm{w}_{2}-\mathrm{w}_{1}} \times \frac{100}{1}$

Where: $\mathrm{W}_{1}=$ weight of empty crucible

$\mathrm{W}_{2}=$ weight of crucible + food before drying or ashing

$\mathrm{W}_{3}=$ weight of crucible + ash

\section{Fat content determination}

The fat content was determined by continuous solvent extraction in a soxhlet reflux apparatus described by James [17]. Exactly $2 \mathrm{~g}$ of the sample was wrapped in a porous paper and carefully placed inside a soxhlet reflux flask. The reflux was mounted on a weighed extraction flask containing $200 \mathrm{ml}$ of petroleum ether on the electro thermal heating mantle. The set was connected to a condenser that cools the evaporated petroleum ether while boiling which in turn fill up the reflux flask. The solvent will extract the oil during the reflux into the boiling flask. This process of boiling, vaporization, condensation and subsequent oil extraction was allowed to continue for 4 hours thereafter the solvent was recovered and the extracted oil was obtained by drying the flask in the oven at $60^{\circ} \mathrm{C}$ for 30 minutes. After cooling in the desiccators, the flask was reweighed. The fat content was calculated thus: 
$\%$ Fat content $=\frac{\mathrm{W}_{2}-\mathrm{W}_{1}}{\mathrm{~W}_{3}} \times \frac{100}{1}$

Where

$\mathrm{W}_{1}=$ Weight of the empty flask

$\mathrm{W}_{2}=$ Weight of flask oil T extract

$\mathrm{W}_{3}=$ Weight of sample used.

\section{Crude fibre determination}

This was determined according to AOAC [16] protocol. Two grams (2 g) of each sample were digested by boiling with $200 \mathrm{ml}$ of $1.25 \% \mathrm{H}_{2} \mathrm{SO}_{4}$ solution under reflux for $30 \mathrm{~min}$. The digest was allowed to cool and then filtered with Buckner funnel equipped with muslin cloth. The residue was washed thrice with hot water, scooped into a conical flask and digested with $200 \mathrm{ml}$ of $1.25 \%$ $\mathrm{NaOH}$ solution under reflux for 30 min boiling. The digest was cooled, filtered and washed thrice with distilled water. The residue was drained and scooped into a previously dried and weighed crucible and then put into the oven to dry at $105^{\circ} \mathrm{C}$ to a constant weight. The dish with its content was reweighed after drying and then placed in the muffle furnace to ash at temperature of $550^{\circ} \mathrm{C}$ for $3 \mathrm{~h}$. The weight of ash obtained was used to calculate the percent fibre thus:

$\%$ Crude fibre $=\frac{\mathrm{W}_{2-\mathrm{W}_{3}}}{\text { Weight of sample }} \times \frac{100}{1}$

Where:

$\mathrm{W}_{2}=$ weight of crucible + sample after boiling, washing and drying

$\mathrm{W}_{3}=$ weight of crucible + sample as ash

\section{Determination of caloric value}

Caloric value was estimated using Atwater general factor system as described by AOAC [16] by multiplying the proportion of protein, fat and carbohydrate by their respective physiological fuel value of 4,9 , and $4 \mathrm{kcal} / \mathrm{g}$ respectively and taking the sum of their products thus:

$\mathrm{F}_{\mathrm{e}}=(\% \mathrm{CP} \times 4)+(\% \mathrm{CF} \times 9)+(\% \mathrm{CHO} \times 4)$

Where: $F_{e}=$ Food energy (in grain calories)

$\mathrm{CP}=$ Crude protein

$\mathrm{CF}=$ Crude fat

$\mathrm{CHO}=$ Carbohydrate

\section{Determination of vitamin A}

The spectrophotometric method by Onwuka [18] was employed in determination of vitamin A. $5 \mathrm{~g}$ of sample was dissolved in $30 \mathrm{ml}$ of absolute alcohol (ethanol) and $3 \mathrm{ml}$ of $5 \%$ potassium hydroxide was added to it. The mixture was boiled under reflux for 30 minutes, cooled rapidly with running water and filtered. $30 \mathrm{ml}$ of distilled water was added, transferred into a separating funnel and 3 portions of $50 \mathrm{ml}$ of ether were used to wash the mixture. The lower layer was discarded and the upper layer was washed with $50 \mathrm{ml}$ of distilled water. The extract was evaporated to dryness, dissolved in $10 \mathrm{ml}$ of isopropyl alcohol and its absorbance was measured at $325 \mathrm{~nm}$. The vitamin A content of the samples was calculated as shown below.

$$
\text { Vitamin A }(m g / 100 g)=\frac{100 \text { au }}{W} \text { as } x
$$


Where: $\mathrm{au}=$ absorbance of test sample

as $=$ absorbance of standard solution

$\mathrm{c}=$ concentration of the test sample

$\mathrm{w}=$ weight of sample.

\section{Vitamin C determination}

The method of Okwu and Josiah [19] was used. Ten grams (10 g) of sample was extracted with $50 \mathrm{ml}$ EDTA/TCA extracting solution for 1 hour and filtered through a Whatman filter paper into a $50 \mathrm{ml}$ volumetric flask and made up to the mark with the extracting solution. $20 \mathrm{ml}$ of the extract was pipette into a $250 \mathrm{ml}$ conical flask into which $10 \mathrm{ml}$ of $30 \% \mathrm{KI}$ and $50 \mathrm{ml}$ of distilled water were added. This was followed by $2 \mathrm{ml}$ of $1 \%$ starch indicator and titrated against $0.01 \mathrm{ml}$ $\mathrm{CuSO}_{4}$ solution to a dark end point. The vitamin $\mathrm{C}$ content of the samples was calculated as shown below:

$$
\text { Vitamin } C(m g / 100 g)=0.88 \times \frac{100}{10} \times \frac{\text { Vf }}{20} \times \frac{T}{1}
$$

Where: $\mathrm{Vf}=$ Volume of extract

$\mathrm{T}=$ Sample titre - blank titre

\section{Determination of calcium and magnesium}

Calcium and magnesium content of the moi moi were determined by the complexiometric titration method of Onwuka [18]. About $20 \mathrm{ml}$ portion of the extract was dispersed into conical flask and treated with pinches of the masking agents (hydroxylamine hydrochloride, sodium cyanide and sodium potassium ferrocyanide). The flask was shaken to dissolve the mixture; $20 \mathrm{ml}$ of ammonia buffer added to it to raise the $\mathrm{pH}$ to 10.00 and titrated against $0.02 \mathrm{~N}$ EDTA solution using Erichrome Black T as indicator to permanent blue end point. A reagent blank was also titrated same. The titre values represent both $\mathrm{Ca}^{2+}$ and $\mathrm{Mg}^{2+}$ in the test sample. The analysis was repeated to determine $\mathrm{Ca}^{2+}$ alone in the test samples. Titration of calcium alone was done as above, but with $10 \% \mathrm{NaOH}$ in place of ammonia buffer and solechrome dark blue indicator in place of Erichrome black T. Total calcium and magnesium content were calculated separately using the formula below:

$$
\mathrm{Ca} / \mathrm{mg}(\mathrm{mg} / \mathrm{mg})=\underline{100} \times \frac{\mathrm{T}-\mathrm{B}(\mathrm{N} \times \mathrm{Ca} / \mathrm{mg})}{\mathrm{W} \mathrm{Va}} \times \frac{\mathrm{Vf}}{1}
$$

Where $\mathrm{W}=$ Weight of sample

$\mathrm{T}=$ titre value of sample

$\mathrm{B}=$ Titre value of blank

$\mathrm{Ca}=$ Calcium equivalence

$\mathrm{Mg}=$ Magnesium equivalence

$\mathrm{Va}=$ Volume of extract titrated

$\mathrm{Vf}=$ Total volume of extract

$\mathrm{N}=$ Normality of titrant $(0.02 \mathrm{~N}$ EDTA).

\section{Phosphorus determination}

Molybdate method using hydroquinone as a reducing agent described by Onwuka [18] was used. Five grams $(5 \mathrm{~g})$ of the sample in a $50 \mathrm{ml}$ graduated flask was mixed with $10 \mathrm{ml}$ of molybdate mixture and diluted to mark with water. The mixture was then allowed to stand for 30 minutes for colour development thereafter absorbance at $600 \mathrm{~nm}$ against a blank was taken. A curve relating absorbance to phosphorus present and standard curve using phosphorus standard solution were constructed following the same procedure to determine the concentration of phosphorus in the sample thus: 
$\%$ Phosphorus = graph reading $\mathrm{x}$ solution volume

100

\section{pH determination}

The $\mathrm{pH}$ was determined by the method described by Akpakpunam and Sefa-Dedeh [20]. Ten gram $(10 \mathrm{~g})$ of the sample was dissolved in $100 \mathrm{ml}$ of distilled water. The mixture was allowed to equilibrate for $3 \mathrm{~min}$ at room temperature. The $\mathrm{pH}$ was then determined by inserting the electrode of the $\mathrm{pH}$ meter into the sample and the reading taking from the result displayed on the $\mathrm{pH}$ meter.

\section{Colour intensity determination}

Colour intensity was determined using UV-VIS spectrophotometer as described by Sharma [21]. Five grams $(5 \mathrm{~g})$ of the sample was diluted with $50 \mathrm{ml}$ of distilled water, brought to $25-30^{\circ} \mathrm{C}$, placed in a corvette and absorbance readings were taken at $600 \mathrm{~nm}$. The colour intensity was calculated as follows:

Colour intensity $=\frac{\mathrm{A} \times \mathrm{F}}{\text { Weight of sample (g) }}$

Where F: Dilution factor to adjust absorbance

\section{A: Absorbance}

\section{Sensory evaluation}

Organoleptic properties of the moi moi were evaluated using 25 semi-trained panelists randomly selected from the staff and students of Department of Food Science and Technology, Michael Okpara University of Agriculture, Umudike aged between 18 to 35y. The moi moi samples were presented in identical plates with appropriate codes. Portable water was also served to the panelists to rinsing their mouth after each tasting so as not to interfere with the taste of the proceeding samples. Sensory attributes evaluated were appearance, taste, flavour, texture and general acceptability The panelists were instructed to score according to 9-point Hedonic scale where 9 is like extremely, 5 is neither like nor dislike and 1 is dislike extremely [22].

\section{Statistical analysis}

The design was completely randomized design (CRD) and data obtained were subjected to One way analysis of variance of a using the Statistical Package of Social Science version 22. Means were separated using Duncan multiple range test at $95 \%$ confidence level $(\mathrm{p}<0.05)$.

\section{Results and Discussion}

Results of proximate composition of the samples were presented in Table 3. With increasing white maize substitution levels for cowpea, the MC of the moi-moi blends decreased with significant $(\mathrm{p}<0.05)$ variation. The decrease could possibly be due to the ability of maize starch to bind and hold water in their mesh network thereby reducing the available free water. The MC decrease (49.53-37 86\%) was lower than the control sample (50.20\%). Substitution beyond 20\% may likely affect the acceptability as desired texture and flavour will be compromised. Decreasing MC implied increasing dry matter content [23, 24] and crude fibre with their associated health benefits. Therefore, increasing substitution will increase such health benefit of moi-moi provided the acceptability is not affected and may likely decrease salivation, mastication and swallowing [25]. Results obtained in this study (37.86 to $50.20 \%$ ) were higher than $40.14 \%$ to $49.89 \%$ reported for plant ash fortified moi-moi prepared from cowpea [26] probably due to fortification. Lower MC $(50.20 \%)$ of the control sample than $55.40 \%$ reported for cowpea [27] could be traced to variety and bean: water ratio used. 
Protein is endowed with a lot of health benefits like maintaining healthy muscle mass, supporting tendon, ligaments and other body-tissue. Protein also helps to prevent kwashiorkor and spikes in blood glucose, which is especially important for preventing type 2 diabetes, balancing energy levels and keeping your appetite and mood in check. Increasing cowpea complementation $(5-20 \%)$ with white maize decreased the protein content of the moi-moi with significant $(\mathrm{p}<0.05)$ variation which likely will affect the associated health benefits. The decrease could be due to dilution effect of the cowpea protein by maize. Cowpea has higher protein content than cereal grains, as evident in $20.70 \%$ from the control sample [15]. Maize is known as carbohydrate-rich crop without substantial amount of crude protein [14]. However, the protein content of the samples is noteworthy since it is higher than 10.42 to $18.69 \%$ reported for plant ash fortified moi-moi produced from cowpea. The lower values could be attributed to protein-calcium interaction [26]. Protein contributes to food flavour.

Results obtained in this study showed significant $(\mathrm{p}<0.05)$ increase $(1.40$ to $1.47 \%)$ in crude fibre content of moi-moi more than the control $(1.37 \%)$ with increasing level of white maize substitution. Therefore, increasing substitution above $20 \%$ may likely increase the associated health benefits provided the acceptability is not affected. Crude fibre reduces the risk of chronic diseases such as diabetes, obesity, cardiovascular disease, and diverticulitis, and lowers cholesterol concentration in the blood and obesity [29]. Fibre is good roughage for intestinal health and weight management [30]. The results obtained in this study was within $1.35 \%$ to $2.00 \%$ reported for moimoi produced from blends of cowpea and bambara nut [1] which could be attributed to variation in raw materials used as well as processing techniques used. But the results are higher than $1.27 \%$ to $1.37 \%$ reported from plant ash fortified moi-moi produced from cowpea [26].

Significant $(\mathrm{p}<0.05)$ decreasing fat content of the cowpea-white maize moi-moi samples with increasing white maize substitution levels portends lowering of energy, fat soluble vitamins, mouth feel, flavour and palatability. The decrease, (10.02\% (CP95:WM5 to 8.64\% (CP80:WM20)) was below $10.67 \%$ from the control sample. But increasing substitution beyond $20 \%$ could likely increase stickiness to the wrapping materials and decrease acceptability as fat acts as releasing agent and flavour enhancer. Energy level will also be decreased.

Table 3: Effect of white maize substitution of cowpea on proximate composition of moi-moi produced from the blends $(\%)$

\begin{tabular}{cccccccc}
\hline Samples & $\begin{array}{c}\text { Moisture } \\
\text { content }\end{array}$ & $\begin{array}{c}\text { Crude } \\
\text { protein }\end{array}$ & Crude fibre & Fat content & Ash content & $\begin{array}{c}\text { Carbohydrate } \\
\text { content }\end{array}$ & $\begin{array}{c}\text { Energy } \\
\text { value } \\
\text { Kcal })\end{array}$ \\
\hline CP100:WM0 & $50.20^{\mathrm{a}} \pm 0.28$ & $20.70^{\mathrm{a}} \pm 0.01$ & $1.37^{\mathrm{d}} \pm 0.02$ & $10.67^{\mathrm{a}} \pm 0.02$ & $1.38 \mathrm{c} \pm 0.02$ & $15.70^{\mathrm{d}} \pm 0.32$ & $241.57^{\mathrm{c}} \pm 1.03$ \\
CP95:WM5 & $49.33^{\mathrm{b}} \pm 0.03$ & $20.52^{\mathrm{a}} \pm 0.01$ & $1.40^{\mathrm{cd}} \pm 0.00$ & $10.02^{\mathrm{b}} \pm 0.03$ & $1.41^{\mathrm{bc}} \pm 0.00$ & $17.31^{\mathrm{c}} \pm 0.01$ & $241.50^{\mathrm{c}} \pm 0.37$ \\
CP90:WM10 & $40.09^{\mathrm{c}} \pm 0.01$ & $19.90^{\mathrm{b}} \pm 0.01$ & $1.43^{\mathrm{bc}} \pm 0.01$ & $9.63^{\mathrm{c}} \pm 0.03$ & $1.44^{\mathrm{b}} \pm 0.01$ & $27.52^{\mathrm{b}} \pm 0.02$ & $276.31^{\mathrm{b}} \pm 0.20$ \\
& & & & & & & \\
CP80:WM20 & $37.86^{\mathrm{d}} \pm 0.03$ & $18.82^{\mathrm{c}} \pm 0.01$ & $1.47^{\mathrm{a}} \pm 0.01$ & $8.64^{\mathrm{d}} \pm 0.01$ & $1.70^{\mathrm{a}} \pm 0.00$ & $31.51^{\mathrm{a} \pm 0.04}$ & $279.08^{\mathrm{a}} \pm 0.01$ \\
\hline
\end{tabular}

a-d: Values are means \pm standard deviation of triplicate determinations. Mean values in the same column with different superscript are significantly different $(\mathrm{p}<0.05)$. CP- cowpea and WM- white maize. 
Ash content results obtained in this study (1.41 to $1.70 \%$ ) were lower than 2.50 to $3.50 \%$ reported for moi-moi produced from maize, improved maize and beans [27]. Bean and maize varieties used could be responsible for the ash variations. Increasing white maize substitution levels (5 to $20 \%$ ) resulted to a corresponding ash increase (1.41(CP95:WM5) to 1.70\% CP80:WM20) with significant variation. The increase which could be attributed to higher mineral content of white maize than cowpea [31, 32] was mineral enrichment as it is also higher than the control sample (1.38\%). Ash is an index of total minerals content in foods and a viable tool for nutritional evaluation of mineral [33]. Therefore, white maize substitution is mineral improvement which levels of addition will depend on acceptability of the moi-moi.

Carbohydrate content of cowpea-white maize moi-moi samples increased from 17.31 to $31.51 \%$ with increasing level of white maize addition possibly due to higher carbohydrate content of white maize than cowpea [32]. These increases were higher than the control sample $(15.70 \%)$ and will be an improvement in energy and texture. Increasing beyond $20 \%$ may likely increase the carbohydrate content more; but that becomes a matter of choice. These results are lower than 18.28 to $36.0 \%$ reported for plant ash fortified moi-moi produced from cowpea [26], and higher than 16.35 to $34.65 \%$ reported for bambara-cowpea moi-moi [1].

Energy values of the cowpea-white maize moi-moi samples were significantly $(\mathrm{p}<0.05)$ improved $(241.50$ to $279.08 \mathrm{Kcal})$ more than the control sample $(241.37 \mathrm{Kcal})$ with increasing white maize substitution. The increment may be due to higher carbohydrate and content of white maize than cowpea which are good energy substrates. Dietary energy is needed for basal metabolic rate, physical activities and aeration of new tissue during growth and pregnancy [34].

Vitamin composition of the moi-moi samples are presented in Table 4. Vitamin A content increase with increasing levels of white maize substitution of cowpea signified improvement in the moi-moi samples. The significant $(\mathrm{p}<0.05)$ improvement is justified by higher vitamin $\mathrm{A}$ increase (1.55 to $1.63 \mu \mathrm{g} / 100 \mathrm{~g})$ than the control sample $(1.23 \mu \mathrm{g} / 100 \mathrm{~g})$ which may have stemmed from higher value in white maize than cowpea. Vitamin A is a fat-soluble antioxidant that plays a critical role in maintaining healthy vision, neurological function, healthy skin and support immune function. It is involved in reducing inflammation through fighting free radical damage. The values obtained in this study exceeded 1.15 and $1.25 \mu \mathrm{g} / 100 \mathrm{~g}$ obtained respectively from maize and bean moi-moi, but lower than $2.67 \mu \mathrm{g} / 100 \mathrm{~g}$ from improved maize moi-moi [27]. Therefore, cowpea-white maize moi-moi could be beneficial for sight improvement especially for vulnerable low income earners.

Vitamin $\mathrm{C}$ is water soluble vitamin responsible for bone and joint development, maintaining healthy immune system, purifies the blood, acts as an antioxidant and nutrient absorption [35]. Vitamin $\mathrm{C}$ did not improve with increasing white maize substitution rather it decreased lower than control sample $(0.07 \mathrm{mg} / 100 \mathrm{~g})$ without significant $(\mathrm{p}<0.05)$ variation, Therefore, the health benefits will be compromised with increasing white maize substitution. Low vitamin $C$ content of the samples could be attributed to poor source and cooking effect as vitamin $\mathrm{C}$ is water soluble and, heat and light labile. 
Table 4: Effect of white maize substitution of cowpea on vitamin composition of moi-moi produced

\begin{tabular}{ccc}
\hline Samples & Vitamin A $(\mu \mathrm{g} / 100 \mathrm{~g})$ & $\begin{array}{c}\text { VitaminC }(\mathrm{mg} / \\
100 \mathrm{~g})\end{array}$ \\
\hline CP100: WM0 & $1.23^{\mathrm{d}} \pm 0.04$ & $0.07^{\mathrm{a}} \pm 0.04$ \\
CP95: WM5 & $1.33^{\mathrm{c}} \pm 0.04$ & $0.04^{\mathrm{b}} \pm 0.00$ \\
CP90: WM10 & $1.45^{\mathrm{b}} \pm 0.07$ & $0.03^{\mathrm{b}} \pm 0.00$ \\
CP80: WM20 & $1.63^{\mathrm{a}} \pm 0.04$ & $0.03^{\mathrm{b}} \pm 0.01$
\end{tabular}

a-d: Values are means \pm standard deviation of duplicate determination. Mean values in the same column with different superscript are significantly different $(\mathrm{p}<0.05)$. CP- cowpea and WM- white maize.

The results are presented in Table 5.Calcium content increased from 17.07 to $18.94 \mathrm{mg} / 100 \mathrm{~g}$ with increasing level of white maize substitution from 5\% (CP95:WM5) to 20\% (CP80: WM20), due to the significant amount of calcium present in maize [14]. The significant $(p<0.05)$ increases signified calcium improvement along with the health benefits as they were higher than the control $(15.33 \mathrm{mg} / 100 \mathrm{~g})$. The values obtained in this study were within $12.10-19.10 \mathrm{mg} / 100 \mathrm{~g}$ reported for maize, improved maize and beans moi-moi [27]. Calcium is important in the body for building and maintenance of teeth and it plays a key role in our cells. It is advisable for adults to consume a calcium rich diet to maintain bone strength [36].

Magnesium content of the samples increased $(12.38$ to $13.17 \mathrm{mg} / 100 \mathrm{~g})$ more than the control $(9.33 \mathrm{mg} / 100 \mathrm{~g})$ with significant $(\mathrm{p}<0.05)$ variation as the level of white maize substitution increased because maize contains reasonable amount of magnesium [27]. The increase was magnesium improvement which was higher than 8.00 to $9.20 \mathrm{mg} / 100 \mathrm{~g}$ ) reported for moi-moi produced from maize and beans [27]. The increases confirm the report that maize has reasonable amount of magnesium [31]. This is beneficial since magnesium is a cofactor in more than 300 enzyme systems that regulate diverse biochemical reactions in the body, including protein synthesis, muscle and nerve function, blood glucose control, and blood pressure regulation [37]. It is required for energy production, oxidative, phosphorylation and glycolysis. It contributes to the structural development of bone and is required for the synthesis of DNA, RNA and the antioxidant glutathione. Phosphorus synergizes with calcium to form calcium phosphate, a predominant bone mineral for strong bones and teeth.

Table 5: Mineral composition of moi-moi produced from cowpea-white maize blend (mg/100g)

\begin{tabular}{cccc}
\hline Samples & Calcium & Magnesium & Phosphorous \\
\hline CP100: WM0 & $15.33^{\mathrm{d}} \pm 0.04$ & $9.33^{\mathrm{c}} \pm 0.04$ & $6.92^{\mathrm{d}} \pm 1.35$ \\
CP95: WM5 & $17.07^{\mathrm{c}} \pm 0.02$ & $12.38^{\mathrm{b}} \pm 0.05$ & $7.20^{\mathrm{c}} \pm 0.07$ \\
CP90: WM10 & $17.84^{\mathrm{b}} \pm 0.02$ & $12.83^{\mathrm{b}} \pm 0.01$ & $7.53^{\mathrm{b}} \pm 0.04$ \\
CP80: WM20 & $18.94^{\mathrm{a}} \pm 0.01$ & $13.17^{\mathrm{a}} \pm 0.02$ & $9.13^{\mathrm{a}} \pm 0.04$
\end{tabular}

a-d: Values are means \pm standard deviation of triplicate determination. Mean values in the same column with different superscript are significantly different $(\mathrm{p}<0.05)$. 
There is significant $(\mathrm{p}<0.05)$ phosphorous improvement $(7.20$ to $7.53 \mathrm{mg} / 100 \mathrm{~g})$ on the $\mathrm{moi}$ moi samples more than the control sample $(6.92 \mathrm{mg} / 100 \mathrm{~g})$ with increasing white maize substitution. The improvement could stem from higher mineral content of maize than cowpea [32]. Phosphorous content could be improved more than this at substitution levels higher than $20 \%$ provided the acceptability is not compromised. Phosphorous is essentially needed for growth and repair of body cells and tissues.

The physicochemical results were presented in Table 6. With increasing white maize substitution level, the $\mathrm{pH}$ (5.83 to 6.05) of the samples decreased below the control sample (6.12) with significant $(\mathrm{p}<0.05)$ variation. This decrease signified increasing acidity and if lower than 5 may result to rejection especially if the substitution level is beyond $20 \%$. Also, the decease may have stemmed from steeping which decreased the maize $\mathrm{pH}$. However, the $\mathrm{pH}$ of the samples is moderately acidic, which may be an advantage because it may not encourage the growth of pathogens that may cause gastrointestinal problems.

Table 6: Physicochemical composition of moi-moi samples from cowpea and white maize blends

\begin{tabular}{ccc} 
Samples & $\mathrm{pH}$ & Colour Intensity \\
\hline CP100: WM0 & $6.12^{\mathrm{a}} \pm 0.00$ & $0.18^{\mathrm{c}} \pm 0.00$ \\
CP95: WM5 & $6.05^{\mathrm{ab}^{\mathrm{b}} \pm 0.07}$ & $0.13^{\mathrm{d}} \pm 0.01$ \\
CP90: WM10 & $5.97^{\mathrm{bc}} \pm 0.01$ & $0.20^{\mathrm{b}} \pm 0.00$ \\
CP80: WM20 & $5.83^{\mathrm{c}} \pm 0.04$ & $0.29^{\mathrm{a}} \pm 0.01$
\end{tabular}

a-d: Values are means \pm standard deviation of duplicate determination. Mean values in the same column with different superscript are significantly different $(\mathrm{p}<0.05)$.

Increasing white maize substitution levels (5 to $20 \%)$ resulted to significant $(\mathrm{p}<0.05)$ colour increase $(0.13$ to 0.29$)$. The increase which was more than the control sample $(0.18)$ implied enhancement of aesthetic appeal and acceptability of cowpea-white maize moi-moi as colour provokes acceptability. Colour intensity refers to the brightness or dullness of a product. The aesthetic appeal of the moi-moi could be increased beyond this by complimenting with more than $20 \%$ of white maize provided acceptability is not compromised. This colour increase may stem from direct effect of heat (Maillard browning) which may have caramelized the hydrolyzed maize sugar [1] during steeping and boiling.

Results of sensory scores were presented in Table 7.The taste scores of cowpea-white maize moi-moi samples decreased from 6.75 (CP95:WM5) to 5.54 (CP80:WM20) with significant $(\mathrm{p}<0.05)$ variation as white maize substitution levels increased (5 to $20 \%)$. The decrease which was lower than control sample (7.75) was taste reduction and could possibly be due to panelist's familiarity with $100 \%$ cowpea moi-moi which was diluted by maize. The control sample (CP100:WM0) was best preferred, followed by sample containing 5\% white maize addition (CP95: WM5) which portends that substitution beyond $5 \%$ will compromise the taste.

Texture scores also decreased significantly $(\mathrm{p}<0.05)$ from 6.50 (CP95:WM5) to 6.15 (CP80:20WM) lower than control sample (7.05) with increasing white maize substitution levels. Significantly, increasing complementation of cowpea with white maize may have resulted to harder textured moi-moi samples due to higher carbohydrate content of white maize which the panelists were not use to. Increasing substitution beyond $20 \%$ may likely compromise texture as the samples were liked slightly below 20\% substitution levels unlike control which was liked moderately. 
From the scores (6.45 to 5.80), appearance of the substituted moi-moi samples increased with significant $(\mathrm{p}<0.05)$ variation as white maize substitution levels increased, but lower than control (6.85). The increase could stem from steeping and higher carbohydrate content of white maize than cowpea. Substitution level beyond $20 \%$ will increase the texture more than the control but may affect the consumer preference.

The flavour scores decreased without significant $(\mathrm{p}<0.05)$ variations lower than control sample (7.10) with increase in white maize substitution levels. The decrease may be as a result of increasing dilution of the desirable beany flavour conversant to the panelists by white maize. Therefore, increasing substitution is flavour loss which will significantly affect acceptability especially at higher substitution levels (>20\%).

General acceptability decreased with increasing white maize substitution levels with control sample (CP100: WM0) being the most preferred (7.80) followed by 5\% substituted sample (7.10). Generally, it could be inferred that, consumers would prefer the organoleptic properties of moi-moi produced from $100 \%$ cowpea in all the attributes evaluated followed by 5\% substituted sample except in appearance where it scored the least.

Table 7: Effect of white maize substitution of cowpea on sensory scores of moi-moi

\begin{tabular}{llllll}
\hline Samples & Taste & Texture & Appearance & Flavour & $\begin{array}{l}\text { General } \\
\text { Acceptability }\end{array}$ \\
\hline CP100: WM0 & $7.75^{\mathrm{a}} \pm 0.79$ & $7.05^{\mathrm{a}} \pm 0.51$ & $6.85^{\mathrm{a}} \pm 1.35$ & $7.10^{\mathrm{a}} \pm 1.52$ & $7.80^{\mathrm{a}} \pm 1.15$ \\
& & & & & \\
CP95: WM5 & $6.75^{\mathrm{b}} \pm 1.71$ & $6.50^{\mathrm{b}} \pm 0.95$ & $5.80^{\mathrm{c}} \pm 1.77$ & $6.40^{\mathrm{ab}} \pm 1.82$ & $7.10^{\mathrm{b}} \pm 1.17$ \\
CP90: WM10 & $5.90^{\mathrm{c}} \pm 1.37$ & $6.20^{\mathrm{c}} \pm 1.36$ & $6.40^{\mathrm{bc}} \pm 1.19$ & $6.35^{\mathrm{ab}} \pm 1.31$ & $6.08^{\mathrm{c}} \pm 1.47$ \\
& & & & & \\
CP80: WM20 & $5.45^{\mathrm{d}} \pm 1.43$ & $6.15^{\mathrm{cd}} \pm 1.6$ & $6.45^{\mathrm{b}} \pm 1.88$ & $6.25^{\mathrm{abc}} \pm 0.85$ & $5.70^{\mathrm{d}} \pm 1.30$
\end{tabular}

a-d:Values are means \pm standard deviation of duplicate determination. Mean values in the same column with different superscript are significantly different $(\mathrm{p}<0.05) .25$ panelists were used.

\section{Conclusions}

With increasing levels of white maize substitution, crude fibre, ash, carbohydrate, energy, vitamin A, calcium, magnesium, phosphorous, colour and appearance were improved. The improvement was up to $20 \%$ white maize substitution at the expense of acceptability as $5 \%$ substituted moi-moi was the second best behind 100\% cowpea moi-moi, the most preferred. But moisture, protein, fat, vitamin $\mathrm{C}, \mathrm{pH}$, taste, texture, flavour and general acceptability were decreased. With these nutritional and energy improvement, moi-moi samples along other nutritious foods will prevent hidden hunger, weaning deficiencies in infants, protein energy malnutrition and kwashiokor.

\section{Conflict of Interest}

The authors declare that there is no conflict of interest. We are approved of the publication in your journal. 


\section{References}

[1] I. N. Okwunodulu1, G. C. Peter and F. U. Okwunodulu, Proximate quantification and sensorymassessment of moi-moi prepared from bambara nut and cowpea flour blends, Asian Fd. Sci. J. 9(2) (2019) 1-11, Article no.AFSJ.48452 ISSN: 2581-7752.

[2] L.O Akajiaku et al., Influence of sprouted pigeon pea (Cajanuscajan) flour inclusion on sensory qualities of moin-moin. The international J. of Sci. and Tech., 2(12)(2014)122-129.

[3] P. S Mamiro, A. M Mbwaga, J. L Kinabo, Nutritional quality and utilization of local and improved cowpea varieties in some regions in Tanzania. Africa J Food Agric. Nutr. Dev.,. 11 (2011)4490-4506.

[4] I. M. Haruna, A.Usman, Agronomic efficiency of cowpea varieties (Vigna unguiculata L.Walp) under varying phosphorous rates in Lafiya, Nassarawa State, Nigeria. Asian J. of Crop Sci., 5(2) s(2013)209-215.

[5] FAO. Cowpea production data base for Nigeria 1992004. Food and Agriculture Organization. [Online] (2005) http:// www.faostat.fao.org/.

[6] A. A.Olapade et al, Rheological properties and consumer acceptance of moi-moi premix. Nigerian Food J., 23 (2005)144-147.

[7] C. I. Owuamonam et al, Quality characteristics of some tropical legumes flours sprouted paste (moi-moi) Production as affected by seed sprouting. Asian J Biol. Sci., 6(8) (2013)347-355. Doi: 10.3923/ajbs. 2013.347 - 355

[8] N. Frank - Peterside, D. O. Dosumu, H. O. Njoku, Sensory Evaluation and Proximate Analysis of African Yam Beans (Sphenostylis Sterocarpaltarms) Moi moi. J. Applied Sci. and Envir. Manag. 6(2) (2002) 43-48.

[9] C.M.F.Mbofung et al, Physicochemical and functional properties of six varieties of Taro (Colocasia esculenta L. Schott) flour. J. Fd. Tech., 4(2) (2006) 135 - 142

[10] E.A.Udensi, F.C. Ekwu, and J.N. Isinguzo, (2007). Anti-nutrient factors of vegetable cowpea (Sesquipedalis) seeds during thermal processing. Pak. J. Nutr. 6: 194-197.

[11] B.A. Majid et al, Proximate composition, ant nutritional factors and proteins fractions of sugar gum seeds as influenced by processing treatments, Pak. J Nutr. 515 (2006)481-484.

[12] K.S. Sandhu, N. Singh, N.S. Malhi, Some properties of corn grains and their flours I: Physicochemical, functional and chapati-making properties of flours. Food Chem.101 (2007) 938-946.

[13] S.I. Enyisi et al, Chemical and nutritional value of maize and maize products obtained from selected markets in Kaduna State, Nigeria. African J. Fd. Sci. Techn., 5(4) (2014) 100-104.

[14] T.R .Shah, K. Prasad, P. Kumar, Studies on physicochemical and functional characteristics of asparagus bean flour and maize flour. In G. C. Mishra (Ed.), Conceptual frame work innovations in agroecology and food sciences. First edition. New Delhi: Krishi Sanskriti Publications. (2015) pp.103-105.

[15] B. D. Chingakham, K. Archana, K. Anit, Sprouting characteristic sand associated changes, In nutritional composition of cowpea (Vigna unguiculata). J. Fd. Sci. Tech. 32(10) (2015) 6821- 6827.

[16] AOAC, (Official Methods of Analysis, $18^{\text {th }}$ Edition, Association of Official Analytical Chemists, Washington D.C., USA, (2010). 
[17] S.C. James, Analytical chemistry of food. Chapman and Hill Prints, London. (1995) Pp. 25.

[18] G.I. Onwuka, Food Analysis and Instrumentation Theory and Practice. $2^{\text {nd }}$ edt Published by Naphthali Prints. (2018) pp104-121

[19] D.E. Okwu, C. Josiah, Evaluation of chemical composition of two Nigerian medicinal plants. African J. of Biotech..5(4) (2006)357-361.

[20] M.A .Akpapunam, Sefa-Dedeh. Traditional lactic fermentation, malt addition and quality development of maize-cowpea weaning blends. Food Nut, Bull, 16(1995)75-80.

[21] A. Sharma, Colour fundamentals for digital imaging, in digital colour imaging handbook, Sharma G. (ed.), CRC Press, Boca Raton, USA. (2003) Pp. 51-90.

[22] M.O. Iwe, Handbook of Sensory Methods and Analysis. Rojoint Communication Services ltd, Enugu, (2010) pp 75-78

[23] O.T. Adepoju, A.U Etukumoh,. Nutrient composition and suitability of four commonly used local complementary foods in Akwa Ibom State, Nigeria. African J. of Fd., Agric., Nutr. Develop. 14(7) (2014) 9544-9560.

[24] I.N. Okwunodulu et al, Quality parameters of soy-maize akamu paste from maize and sprouted soybean blends and sensory attributes of their gruel for complementary feeding. Sumerianz J. of Nutri. and Fd. Sci., 1 (1) (2020) 33-40.

[25] I.N. Okwunodulu et al, Inter-relationship of dehulling and toasting on the proximate composition and Atwater factor of African bread fruit (treculia africana) seeds, African J. of Agric. Fd. Sci. 1(2) (2018)30- 39)

[26] I. N. Okwunodulu et al, Proximate, mineral and acceptability levels of moi-moi prepared from cowpea (vigna unguiculate (1) walp) and fortified with plant ash water extract, Nig. J. of Agric., Fd. and Env. 16(3): (2020) 101-110.

[27] O.A.W. Ejima, O.S Ejima,. Nutrient potential of improved fresh maize Moi-moi compared with bean Moi-moi. Inter. J Innov. Sci., Eng. and Tech., 2(6) (2015)559-572.

[28] M. Egounlety et al, Nutriti-onal and sensory evaluation of tempeh fortified maize based weaning foods. Inter. J.Fd Sci. Nutr.. 53 (2002) 15-27.

[29] C. N. Ishiwu, V. A.Tope, Effect of period of fermentation on nutrients of Castor oil seed (Ricinus communis).Direct Research J. Agric. Fd. Sci. (DRJAFS).3 (10) (2015)178-183.

[30] SFGATE, Normal Fiber Intake for Children. Healthyeating.sfgate.com/normal-fiber-intakechildren-4548-html. (2017).

[31] C. Gopalan, B.V. Sastri, S. Balasubramanian, Nutritive value of Indian Foods. Published by National Institute of Nutrition (NIN), ICMR. (2007).

[32] M.O. Brownson, Proximate and sensory properties of "Ipekere" produced from yellow maize and beans. J. Sci Tech.. 2(6) (2016) 124-135.

[33] Okwunodulu et al, Quality Characteristics of soy-akamu powder formulated from sorghum and sprouted soybean flour blends for complementary feeding. World J. of Fd. Sci. and Tech., 3(4) (2019) 48-57 http://www.sciencepublishinggroup.com/j/wjfst doi: 10.11648/j.wjfst.20190304.12.

[34] I N. Okwunodulu, M O. Iwe and C. J. Okakpu, Proximate, nutrients and dietary energy profiles of vitamin and mineral fortified pre-digested soymilk for complementary feeding. Inter. J. of Fd. Sci. and Nutr. 5 (4) (2020) 78-85.

[35] MedicineNet (MN). Definition of Ascorbic Acid. Available:https://www.medicinenet.com/script/main/art.asp?articlekey=12536. (2011). 
[36] G. W. Ayoade, I. A. Amoo and E E. Gbolahan-Ayoade, Phytochemical composition and anti-oxidative potential of purple canary (Canarium schweinfurthii) fruit. The Pharm. Innov. J. 4(1) (2015) 49-52.

[37] F. Axe, Manganese Helps Prevent Osteoporosis and Inflammations. http://draxe.com/manganese/ (2018).

[38] L.I.I. Ouoba et al, Volatile compounds of soumbala, a fermented African Locust bean (Parkia biglobosa), Food Condiment. (2005) 33-39. 